\title{
Eye lenses reveal ontogenetic trophic and habitat shifts in an imperiled fish, Clear Lake hitch (Lavinia exilicauda chi)
}

\author{
Matthew J. Young, Veronica Larwood, Justin K. Clause, Miranda Bell-Tilcock, George Whitman, \\ Rachel Johnson, and Frederick Feyrer
}

\begin{abstract}
Stable isotopes recorded in fish eye lenses are an emerging tool to track dietary shifts coincident with use of diverse habitats over the lifetime of individuals. Eye lenses are metabolically inert, sequentially deposited, archival tissues that can open avenues to chronicle contaminant exposures, diet histories, trophic dynamics and migratory histories of individual fishes. In this study, we demonstrated that trophic histories reconstructed using eye lenses can resolve key uncertainties regarding diet and trophic habitat shifts. Clear Lake hitch (Lavinia exilicauda chi), a threatened cyprinid, inhabits a single lake (Clear Lake, Lake County, California) and utilizes tributary streams for reproduction. Bayesian mixing models applied to $\delta^{13} \mathrm{C}$ and $\delta^{15} \mathrm{~N}$ recorded in eye lenses uncovered ontogenetic diet shifts that corresponded with shifts in occupation of habitats providing spawning (tributary streams), rearing (littoral lake), and growth (pelagic lake) functions. The reconstruction of size-structured trophic and habitat information can provide vital information needed to manage and conserve imperiled species such as the Clear Lake hitch.
\end{abstract}

Résumé : Les isotopes stables préservés dans les lentilles des yeux de poissons constituent un nouvel outil pour suivre les variations des régimes alimentaires coïncidant avec l'utilisation d'habitats variés durant la vie d'individus. Les lentilles des yeux sont des tissus inertes sur le plan métabolique déposés séquentiellement qui constituent des archives pouvant servir de registre des expositions aux contaminants, des antécédents d'alimentation, de la dynamique trophique et de l'historique de migrations de poissons individuels. Nous démontrons que les antécédents trophiques reconstitués à l'aide de lentilles d'yeux peuvent résoudre d'importantes incertitudes concernant les changements de régimes alimentaires et d'habitats trophiques. Le cyprinidé menacé (Lavinia exilicauda chi) n'habite qu'un seul lac (Clear Lake, Lake County, Californie) et utilise des affluents pour sa reproduction. Des modèles de mélange bayésiens appliqués au $\delta^{13} \mathrm{C}$ et au $\delta^{15} \mathrm{~N}$ de lentilles d'yeux révèlent des changements ontogéniques du régime alimentaire qui correspondent à des changements de l'occupation d'habitats assurant des fonctions de frai (affluents), d'élevage (lac littoral) et de croissance (lac pélagique). La reconstitution de l'information trophique et sur l'habitat structurée par âge peut fournir des renseignements clés pour la gestion et la conservation d'espèces en péril comme Lavinia exilicauda chi. [Traduit par la Rédaction]

\section{Introduction}

Many fish species utilize different habitats across ontogeny, including large-scale migrations across the landscape (e.g., ocean basin migrations, Block et al. 2001; anadromy, Clemens et al. 2010) or smaller-scale movements into different local habitats (e.g., marine vertical migration, Hawes et al. 2020; offshore migrations in lakes, Maciej Gliwicz et al. 2006). Identifying how and when individuals use these habitats is fundamental to the conservation of many migratory species (Runge et al. 2014), but reconstructing these life histories, especially during early life stage transitions, can be challenging. Traditional sampling techniques are hampered by inefficiency and spatiotemporal uncertainty, and physical tagging and (or) tracking methods can be logistically prohibitive or impossible.

To get around these limitations, tissues that act as chemical archives have been increasingly utilized to reconstruct the life histories of individual fishes (Secor et al. 1995; Tzadik et al. 2017). During tissue formation and deposition these tissues uptake environ- mental constituents and are subsequently metabolically inert, meaning that there is no further resorption or chemical alteration of the tissue. These tissues thus act as faithful recorders of environmental conditions at the time of tissue formation. Further layers are sequentially added, continuing to reflect the local environment. Microchemistry in otoliths has been used to identify movements or origins based on natural water chemistry (Secor et al. 1995; Campana 1999; Ingram and Weber 1999), exposure to localized contaminants (Dove and Kingsford 1998; Johnson et al. 2020), and other environmental conditions (Limburg et al. 2015). Similarly, fish endoskeletons, fin spines, and fin rays allow for reconstruction of lifetime biochemical data (Tzadik et al. 2017). Eye lenses are a metabolically inert, proteinaceous tissue type that has also been successfully used to reconstruct biochemical data for individual fishes (Wallace et al. 2014; Quaeck-Davies et al. 2018; Bell-Tilcock et al. 2021) and cephalopods (Parry 2003; Hunsicker et al. 2010).

The eye lens grows over the lifetime of an individual fish by sequentially adding fibrous cytosolic protein layers (or laminae)

Received 20 August 2020. Accepted 24 May 2021.

M.J. Young, V. Larwood, J.K. Clause, and F. Feyrer. US Geological Survey, California Water Science Center, 6000 J Street, Sacramento, CA 95819, USA. M. Bell-Tilcock and G. Whitman. University of California Davis, Center for Watershed Sciences, 1 Shields Avenue, Davis, CA, USA.

R. Johnson. University of California Davis, Center for Watershed Sciences, 1 Shields Avenue, Davis, CA, USA; NOAA Fisheries, Southwest Fisheries Science Center, Fisheries Ecology Division, 110 McAllister Way, Santa Cruz, CA, USA.

Corresponding author: Matthew Young (email: mjyoung@usgs.gov).

() 2021 The Author(s). This work is licensed under a Creative Commons Attribution 4.0 International License (CC BY 4.0), which permits unrestricted use, distribution, and reproduction in any medium, provided the original author(s) and source are credited. 
Fig. 1. Conceptual model indicating functional habitats utilized by Clear Lake hitch across ontogeny. There is diversity in individual timing of shifts across habitats. Displayed $\delta^{13} \mathrm{C}$ values reflect prey isotopic composition from different habitats (Eagles-Smith et al. 2008a). [Colour online.]

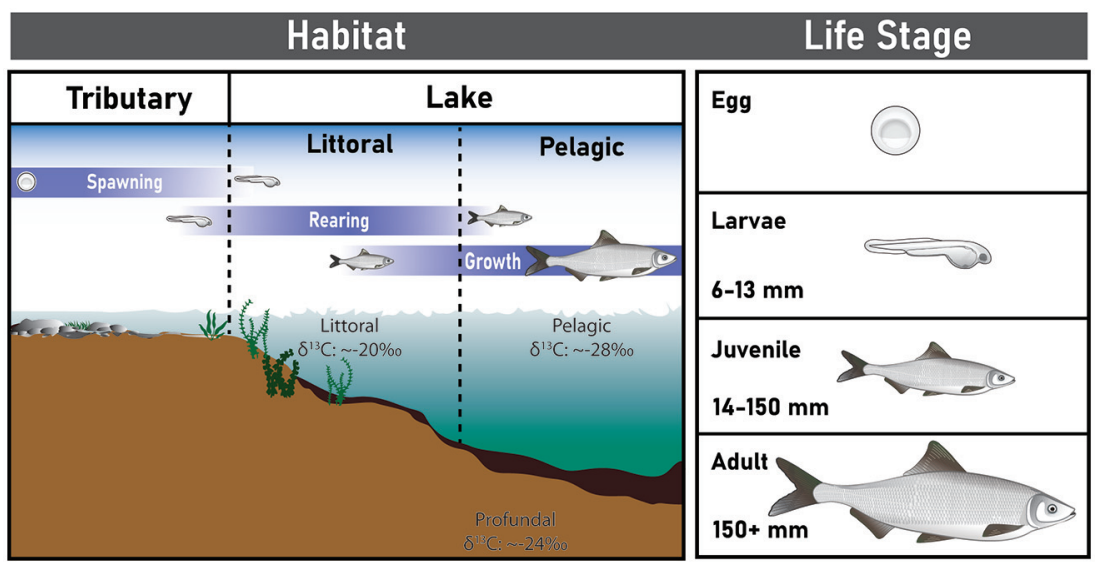

to the lens surface, with older layers near the central core and younger layers added on top (Nicol and Somiya 1989; Bloemendal et al. 2004; Dahm et al. 2007). This process starts early in embryonic development and continues throughout the individuals' lifespan, leaving a biochemical record across ontogeny (Dahm et al. 2007; Wallace et al. 2014). Eye lens volume increases throughout a fish's lifetime (Bassnett and Beebe 1992) but the lens growth rate declines (Bron et al. 2000), which creates a direct relationship between lens diameter and total body size (Quaeck-Davies et al. 2018; Vecchio et al. 2021). The proteinaceous lens material bonds well with covalently bonded contaminants (e.g., $\mathrm{Pb}, \mathrm{Hg}$; Dove and Kingsford 1998) and contains carbon, nitrogen and sulfur, facilitating lifetime biochemical reconstruction and associated ecological interpretation. Thus, eye lenses can complement analysis of other structures with different chemical composition (e.g., largely calcium carbonate structures such as otoliths).

Eye lenses have successfully been used to recreate contaminant exposure (Dove and Kingsford 1998; Kingsford and Gillanders 2000), trophic histories (Simpson et al. 2019; Kurth et al. 2019; Curtis et al. 2020), and geographic histories (Kurth et al. 2019; Peebles and Hollander 2020, Vecchio and Peebles 2020; Bell-Tilcock et al. 2021, Vecchio et al. 2021) of marine fishes and cephalopods (Meath et al. 2019; Liu et al. 2020). In these examples, data gained from eye lens tissue has been used to reconstruct broad ontogenetic movements (particularly when other tissue types such as otoliths are unsuitable; Meath et al. 2019; Kurth et al. 2019) and evaluate diet overlap amongst sympatric species (Simpson et al. 2019). To date, examples of further ecological interpretation are few, especially with respect to freshwater systems (see exception Bell-Tilcock et al. 2021). However, Quaeck-Davies et al. (2018) identified three key uncertainties that need to be tested prior to application of SIA in eye lenses: establish a species-specific relationship between lens size and fish size, identify the relationship between lens protein stable isotope composition and conventional tissues like white muscle, and evaluate the consistency of isotopic patterns within and among individuals.

The Clear Lake hitch (Lavinia exilicauda chi) is a potamodromous cyprinid endemic to a single freshwater lake (Clear Lake, California, USA), and provides an opportunity for ecological interpretation and validation. The Clear Lake hitch is currently listed as threatened by the state of California and long-term survival projections are bleak (Moyle et al. 2013). Recent research using otolith chemical markers (stable isotopes of strontium, Sr) has resolved key uncertainties regarding the natal origin of individual Clear Lake hitches, the age at which individuals leave spawning tributaries and enter the lake and identified local watersheds important to local production and recruitment (Feyrer et al. 2019a). Despite this advance, there remain key uncertainties about habitat use once Clear Lake hitches enter the lake. After leaving spawning tributaries juvenile fish are presumed to rear in littoral habitats until approximately $50 \mathrm{~mm}$ standard length (SL) and then migrate offshore into pelagic habitats for growth until reproductive maturity where they return to tributaries to spawn (Geary 1978; Moyle 2002; Fig. 1). However, this is largely based on anecdotal capture information predating non-native species introductions, which have significantly modified the lake's ecology (Eagles-Smith et al. 2008a), and field observations (Feyrer et al. 2019b).

Given large-scale changes to the ecology of Clear Lake and population declines, this study updates understanding of diet and critical habitat used by Clear Lake hitch across ontogeny, particularly with respect to within-lake shifts in rearing (littoral) and growth (pelagic) habitats. This study also expands method validation of stable isotope analysis (SIA) in eye lenses, necessary for opening avenues for use in native fish conservation. Here, we (1) assess the suitability of eye lenses for recreation of Clear Lake hitch isotopic histories and (2) use them to identify ontogenetic trophic habitat shifts and compare the results with similar analyses using muscle tissue. This study demonstrates the value of eye lenses for recreating diet-based migration histories, updates current understanding of Clear Lake hitch ecology, and highlights the importance of including multiple archival tissue types in reconstructing the life history of imperiled freshwater fishes.

\section{Materials and methods}

\subsection{Study area}

Clear Lake, located in central California, USA, is the largest freshwater lake within California (Fig. 2). When full, Clear Lake has a surface area of $\sim 17700$ ha, a total volume of $\sim 1.4 \times 10^{9} \mathrm{~m}^{3}$, a mean depth of $\sim 7 \mathrm{~m}$, and is seasonally hypereutrophic. Inflow comes from several intermittent streams (predominantly Adobe and Kelsey creeks), which are driven by seasonal rains associated with the local Mediterranean climate. These ephemeral waterways provide the majority of Clear Lake hitch spawning habitat (Feyrer 2019; Feyrer et al. 2019a). A legacy of surface mining, local agriculture, and non-native species introductions have caused major changes to the ecology of the lake, including elevated environmental mercury (Hg) levels (Suchanek et al. 2008, 2009), habitat degradation (Suchanek 2003; Richerson et al. 2008), and local extinctions and extirpations (Thompson et al. 2013).

\subsection{Fish collection and laboratory methods}

Individual Clear Lake hitches were collected during a broad habitat association study in June and July of 2017 using experimental 
Fig. 2. Map of Clear Lake showing sites where fish were collected. Lake collection locations are denoted with a plus and stream collection locations are denoted with a triangle. Major intermittent tributaries (Adobe and Kelsey creeks) and perennial outflow (Cache Creek) noted. The map was prepared using ArcGIS Pro (Version 2.5.0; Esri, Redlands, California, USA). Waterways obtained from the CDFW GIS Clearinghouse (https://wildlife.ca.gov/Data/GIS/Clearinghouse), political boundaries obtained from the USGS National Map (https://apps. nationalmap.gov/), Lake County topography from NOAA (OCM Partners 2021), and sampling locations from Steinke et al. 2019. [Colour online.]

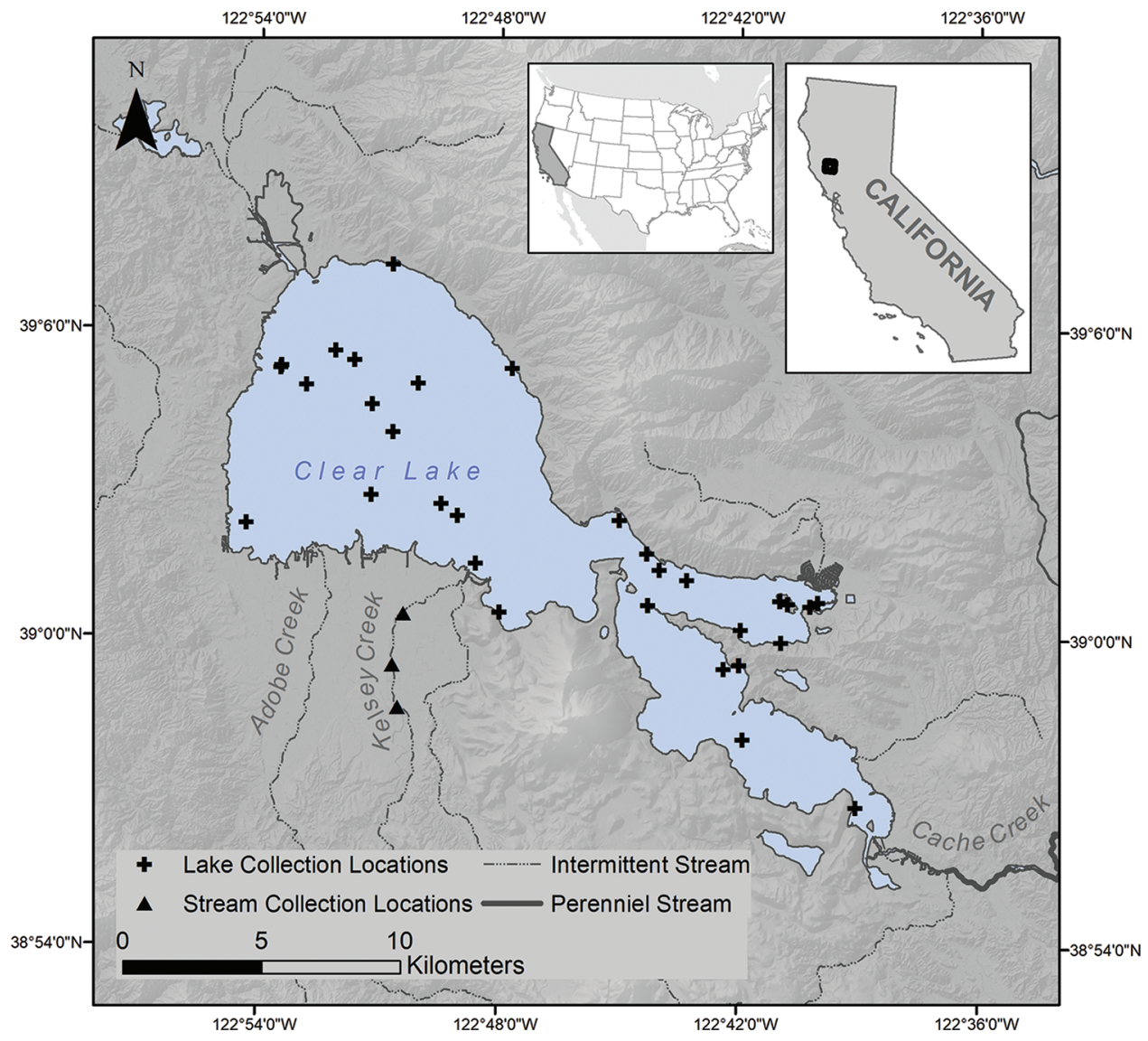

gill nets deployed at randomized sites (Fig. 2; for more detail see Feyrer et al. 2019b). The protected status of the Clear Lake hitch constrained the number of individuals that could be retained for scientific study; therefore 45 individuals were collected from 32 locations, with one additional incidental mortality retained from an additional location for a total of 46 individuals. One juvenile Clear Lake hitch and ten juvenile Clear Lake roach (Hesperoleucus venustus $\times$ H. symmetricus) were collected from Kelsey Creek (Lake Co.; Fig. 2) for size validation in May 2020. Clear Lake roach were included for size validation as it is a closely related and morphologically similar species (Baumsteiger and Moyle 2019; Baumsteiger et al. 2019). Individual fishes were weighed and measured prior to dissection. Both eyes of each fish were carefully extracted so as not to puncture the sclera and each eye was frozen intact. Each adult fish was filleted, with at least $5 \mathrm{~g}$ of left posterior dorsal muscle tissue removed and frozen. Each adult fish also had lapilli otoliths removed for a separate analysis (Feyrer et al. 2019a).

Eye lenses were removed from the left eye of each fish, and the diameter of each intact eye lens was measured using a dissecting microscope (set at $20 \times$ magnification) and digital camera (Moticam BTU 8). Each lens was dissected, with individual layers physically removed one at a time (delamination) using forceps. The eye was thawed and wetted with deionized water per established methods (Wallace et al. 2014; Bell-Tilcock et al. 2021) to avoid contamination observed using embedding techniques (Quaeck-Davies et al. 2018). After the removal of each layer the diameter of the remaining intact lens was measured. Once the intact lens reached a diameter of less than $500 \mu \mathrm{m}$ the remaining material was described as the "core" of the eye lens. This core was typically denser than the surrounding layers and further delamination was difficult. Each lens layer, including the core, was placed in a tin capsule. Eye lens material was dried for 12 hours prior to submission for SIA. For validation purposes ten percent of sampled individuals were selected at random and had both eye lenses delaminated and analyzed. Muscle fillets were dried at $60{ }^{\circ} \mathrm{C}$ for a minimum of 24 hours, ground to a fine powder, and then a subsample was placed in tin capsules for SIA. All tissues were analyzed for $\delta^{13} \mathrm{C}$ and $\delta^{15} \mathrm{~N}$ at the University of California, Davis, Stable Isotope Facility using a PDZ Europa ANCA-GSL elemental analyzer interfaced to a PDZ Europa 20-20 isotope ratio mass spectrometer (IRMS; Sercon Ltd., Cheshire, UK). We did not correct for lipid content (Post et al. 2007) as C:N ratios were generally low ( 3.5). All isotope values are expressed relative to international standards Vienna PeeDee Belemnite (V-PDB) and air for carbon and nitrogen, respectively.

\subsection{Data analysis}

\subsubsection{Assess eye lens suitability for recreation of Clear Lake hitch isotopic histories}

Prior to trophic habitat analysis, we assessed eye lens suitability by (1) using a lens diameter and fish length relationship to reconstruct size-calibrated isotopic histories and (2) establishing relationships between stable isotopes in eye lenses and those in muscle tissue. First, for each fish we had a measurement of intact 
eye lens diameter and fish size. To verify the relationship across ontogeny we included post-larval individuals collected in the tributaries. We used simple linear regression to develop a relationship between the two parameters and used it to estimate the lens size of a newly hatched individual (6 mm; Swift 1965). To assess consistency between eye lenses of the same individuals we used an ANCOVA to test for an effect of eye side (left or right) on the relationship between isotope values and fish size. We then applied this relationship to intermediate lens diameters measured during lens delamination and assigned an estimated fish size (standard length in millimetres) to each intermediate layer.

Second, we directly compared the stable isotope composition of fish muscle tissue and the eye lens to evaluate tissue-specific fractionation for further statistical analysis. Fish muscle tissue has an approximate isotopic turnover time of weeks to months based on fish size (Weidel et al. 2011; Vander Zanden et al. 2015); however, the exact temporal resolution of the eye lens layers is unknown. One estimate for a temporal lag between diet shifts and isotopic expression in the eye lens is $~ 55$ days (Granneman 2018) which is within the range of isotopic turnover in muscle tissue, however it is unclear what temporal window is represented by individual laminae. To address this issue, we compared the weighted averages of the cumulative carbon and nitrogen stable isotope values separately in the five outermost lens layers (layer 1 , layer $1+2$, layer $1+2+3$, etc.) to the isotopic values of muscle tissue.

The volume for each layer was calculated by using the equation for the volume of a sphere $\left(V=4 / 3 \pi r^{3}\right.$, where $r$ is the radius of the sphere) and subtracting the volume left after each subsequent layer's removal $\left(V_{\text {Layer } X}=V_{\text {Diameter } X}-V_{\text {Diameter } X-1}\right)$. We then took a weighted average of the isotopic values based on the relative volumes of each layer used. Using the single outermost layer resulted in high variability in differences between muscle and eye lens tissue (i.e., standard deviation; carbon: 2.68, nitrogen: 1.42) and incorporating additional layers generally reduced variability. The weighted average of the three outermost layers had the lowest standard deviation (carbon: 2.14, nitrogen: 1.16) that did not result in exclusion of any individuals from the dataset (one individual only had 3 layers). We used one-way ANOVA to test for significant differences between eye lens and muscle tissues for both carbon and nitrogen. When significant, we used the mean difference in isotopic values between muscle and the eye lens weighted average to estimate tissue-specific trophic fractionation for further statistical analyses.

\subsubsection{Identification of ontogenetic trophic habitat shifts}

To simultaneously infer Clear Lake hitch habitat utilization and compare eye lens stable isotope data with other tissue types we applied Bayesian mixing models to both eye lens and muscle stable isotope data. Eye lens models allow for determining the relative proportion of pelagic and benthic trophic pathways across a range of fish sizes while using muscle models allowed for validation of eye lens results. Bayesian mixing models of this type incorporate uncertainty in source contributions, including trophic enrichment estimates (Phillips et al. 2014), a common cause of error in stable isotope diet analyses. By incorporating this uncertainty our results are conservative relative to the uncertainty around eye lens trophic enrichment. We used the package MixSIAR 3.1 (Stock and Semmens 2016) in Program R ( $\mathrm{R}$ Core Team 2019) and ran the model using fish size (standard length in millimetres; estimated for the eye lens model and measured for muscle model) as a continuous parameter and individual fish as a random effect. Consumer data for the eye lens model was limited to samples where the estimated fish size was greater than $50 \mathrm{~mm}$ SL to limit maternal and (or) core influences and guarantee exogenous feeding. Both models included process error, which considers source and consumer variation, but did not include residual error, consistent with the application of MixSIAR to models with continuous covariates (Stock and Semmens 2016; Stock et al. 2018). Both models were set to run three chains for 50000 Markov Chain Monte Carlo simulations, with a burn-in of 25000 and thinning of 25. We evaluated model convergence using the Gelman-Rubin diagnostic, ensuring that fewer than $5 \%$ of values exceeded 1.05 .

Source data for both models were obtained from Eagles-Smith et al. (2008a), which demonstrated separation between $\delta^{13} \mathrm{C}$ values in invertebrates representing littoral $(\sim-20 \%)$, profundal $(\sim-24 \%)$, and pelagic habitats $(\sim-28 \%)$. Due to the use of historic data we focused our analysis on a coarse estimation of trophic habitat rather than more nuanced analyses using data from particular diet items. Because $\delta^{15} \mathrm{~N}$ values for these habitats were lacking we only used $\delta^{13} \mathrm{C}$ for mixing model analysis. To minimize underdetermination in a one-dimensional mixing model littoral and profundal values were combined a priori so that mixing models included only two sources, benthic (littoral + profundal: $-22 \% \pm$ $2 \%$ ) and pelagic $(-28 \% \pm \pm 1 \%$; Eagles-Smith et al. 2008a). Trophic discrimination factors for muscle models $(1.1 \pm 0.35)$ were obtained from McCutchan et al. (2003) values for aquatic muscle tissue with standard errors converted to standard deviation per MixSIAR requirements. Trophic discrimination factors for eye lens models $(3.46 \pm 2.17)$ were calculated by summing the offset between eye lens and muscle tissue identified earlier $(2.36 \pm 2.14)$ with the aquatic muscle values from McCutchan et al. (2003) using the following equation to calculate standard deviation for combined discrimination factors:

$$
\mathrm{SD}_{\text {Combined }}=\sqrt{\mathrm{SD}_{1}^{2}+\mathrm{SD}_{2}^{2}}
$$

Model results provided an estimate for the contribution of benthic and pelagic sources to an individual at different lengths. The posterior distributions for all individuals were then summarized to obtain median estimates for source contributions across fish size for each individual and for the sampled population. We then visually compared model output from muscle and eye lens models to assess consistency across tissue types and success of eye lens-based reconstruction. Muscle tissue analysis results were limited by smaller sample sizes (only one sample per fish), and a limited range of collected individual sizes. Thus, model comparisons were only made for sizes well-represented in the muscle tissue dataset (135 and $250 \mathrm{~mm} \mathrm{SL}$ ).

We used median source contribution values of $10 \%, 50 \%$, and $90 \%$ from pelagic sources to identify shifts in trophic habitat (i.e., a median value of $50 \%$ shows the median size where an individual consumed equal amounts of benthic and pelagic prey). For each individual fish we thus had an estimated size at habitat shift (i.e., where pelagic food sources comprised a majority of the contribution). We used collection location and published data on the natal origin and age at lake entry for the same individual fish (Feyrer et al. 2019a) to explore causes of variability in the size of inferred habitat shifts. We used ANOVA to test for differences in size at habitat shift based on collection location and natal origin (stream groupings identified in Feyrer et al. 2019a).

\section{Data availability}

Data collected in support of this study are available in the US Geological Survey's ScienceBase catalog. Isotope data are available from Steinke et al. (2020; doi:10.5066/P98S3SBV) and all other data are available from Steinke et al. (2019; doi:10.5066/ P9A03OI6) and Feyrer (2018; doi:10.5066/P9IX7L5V).

\section{Results}

\subsection{Fish collection summary}

Forty-six individual fish were retained from gill net sampling, ranging in size from 125 to $310 \mathrm{~mm}$ standard length (mean \pm 
Fig. 3. Scatterplot of measured intact eye lens diameter against standard length. Regression line included, with gray ribbon as $95 \%$ confidence intervals around the mean (regression $R_{\mathrm{adj}}^{2}=0.96$, intercept $=-29.7$, slope $=0.093$ ), Hollow point represents the estimated lens size at hatch $(6 \mathrm{~mm})$. Triangles represent Clear Lake hitch $(\mathrm{HCH})$, and circles represent Clear Lake roach $(\mathrm{CRCH})$. [Colour online.]

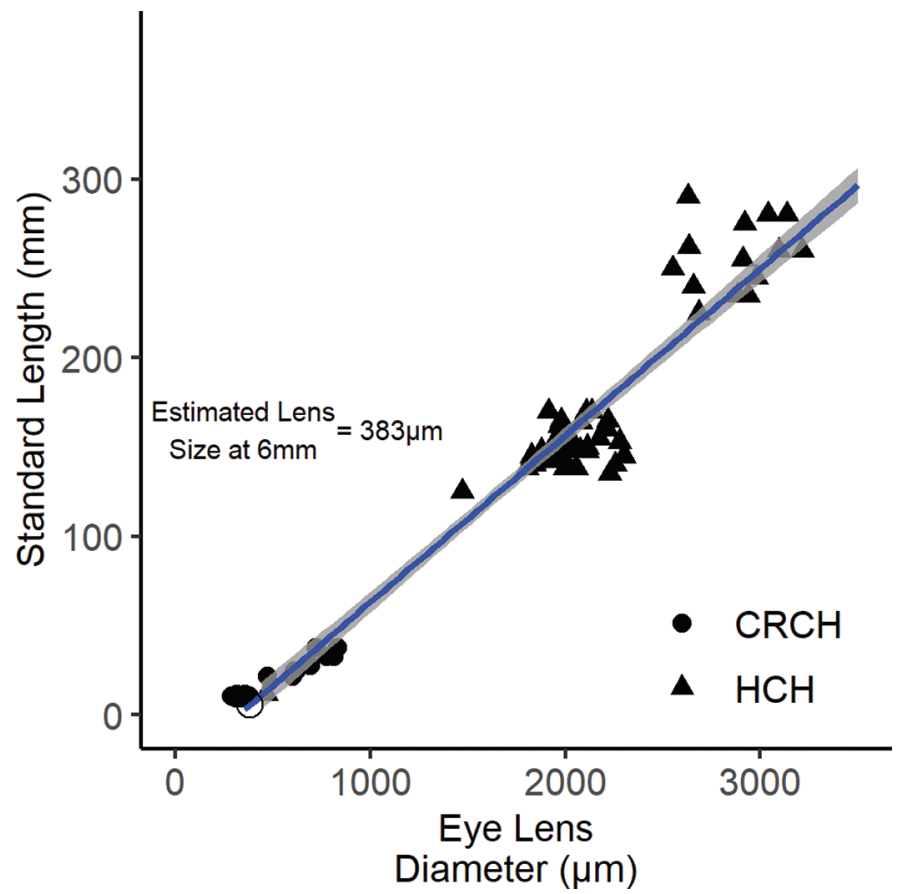

standard deviation: $192 \pm 58 \mathrm{~mm}$ ). Based on published size-age relationships (Geary and Moyle 1980) estimated ages of individual fish ranged from 2 to $5+$ years old. Due to laboratory measurement error one individual was included for eye lens - muscle comparison but excluded from the rest of the analysis. Seven randomly selected individuals had both eyes analyzed. Adult Clear Lake hitch eye lenses averaged approximately 11 layers per lens, and juveniles averaged approximately 6 layers per lens. Juveniles collected in May 2020 included one post-larval Clear Lake hitch ( $\mathrm{SL}=12 \mathrm{~mm}$ ), and ten individual Clear Lake roach (SL ranging between 10 and $38 \mathrm{~mm}$ ).

\subsection{Assess eye lens suitability for recreation of Clear Lake hitch isotopic histories}

There was a significant relationship between fish size and intact eye lens diameter $\left(p<0.001 ; R_{\mathrm{adj}}^{2}=0.96\right)$. Based on regression coefficients (intercept $=-29.6$, slope $=0.093$ ), the estimated eye lens diameter at a standard length of $6 \mathrm{~mm}$ (size at hatch) was $383 \mu \mathrm{m}$ (Fig. 3), which we then used as a lower bound for fish size estimation. This regression was used to estimate fish size for every intermediate lens diameter. Once intermediate sizes were estimated, we were able to establish size-calibrated isotopic histories for each individual fish. These isotopic histories showed ontogenetic shifts for both carbon and nitrogen (Fig. 4). $\delta^{13} \mathrm{C}$ values ranged from $-15.1 \%$ to $-33.6 \%$, and were generally lower near the core, increased in intermediate layers, and then decreased again in the outer layers. $\delta^{15} \mathrm{~N}$ values ranged from $3.5 \%$ to $11.4 \%$ and were higher in the outer layers and lower in intermediate layers and near the core. Core values were lower relative to outer layers for both $\delta^{13} \mathrm{C}$ and $\delta^{15} \mathrm{~N}$ and were removed from further analysis with the assumption that the core represents the maternal contribution to development and not exogenous feeding. Differences between left and right eye lenses sampled from the
Fig. 4. Plot of eye lens stable isotope values against estimated fish size for Clear Lake hitch (A: carbon, B: nitrogen). The gray points and lines represent values from individual fish and the blue line represents a loess curve across all individuals to show broad trends across the sampled population. [Colour online.]
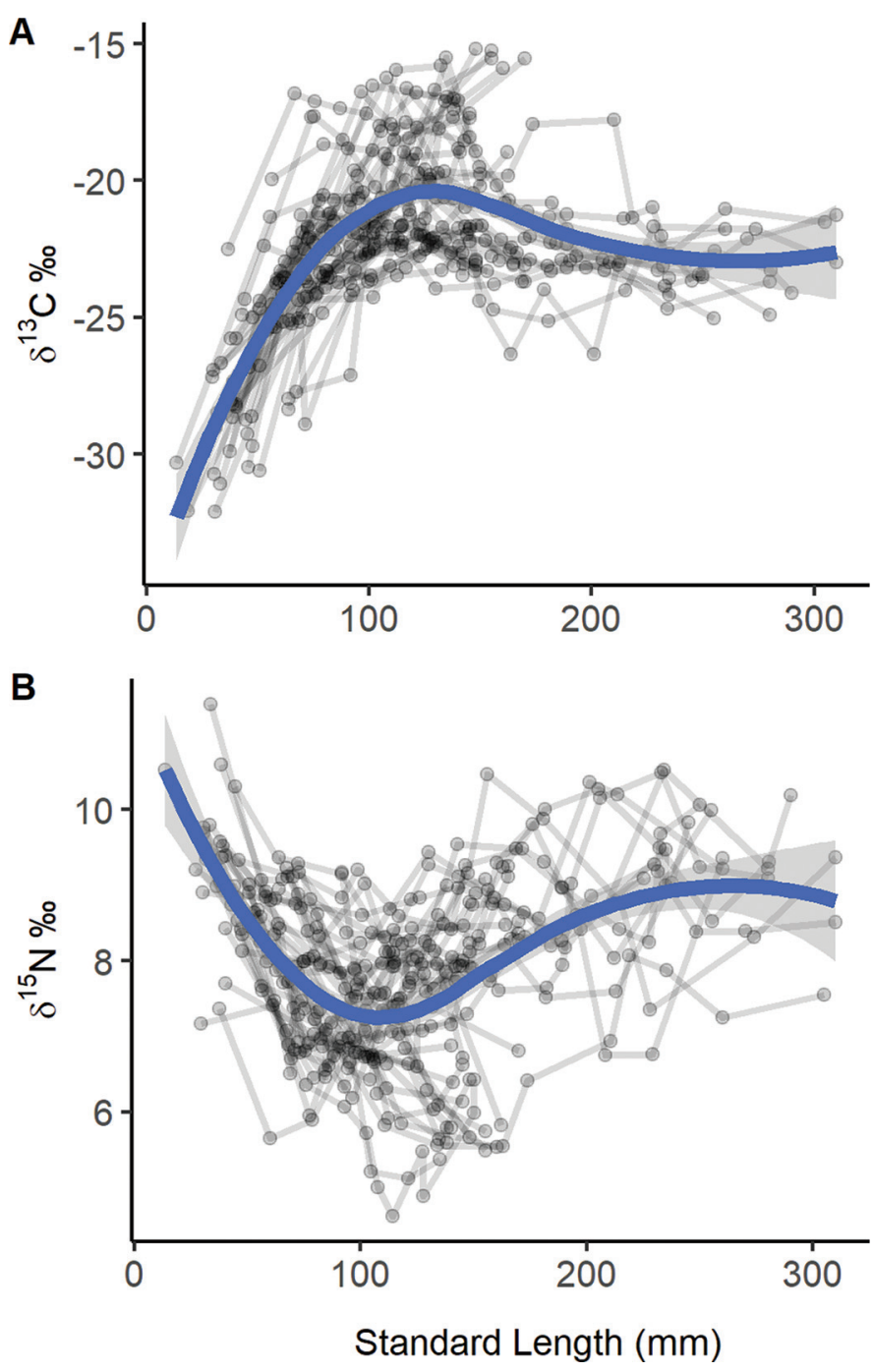

same individual were minimal (Fig. 5), with no significant effect of eye lens side (i.e., left or right) on stable isotope values (ANCOVA; $\delta^{13} \mathrm{C}: \mathrm{F}_{[1,68]}=0.02, p=0.89 ; \delta^{15} \mathrm{~N}: \mathrm{F}_{[1,68]}=0.01, p=0.94$ ).

Muscle tissue stable isotopes significantly differed from the weighted average of the three outermost eye lens layers (ANOVA results: $\left.\delta^{13} \mathrm{C}: \mathrm{F}_{[1,49]}=10.4, p=0.002 ; \delta^{15} \mathrm{~N}: \mathrm{F}_{[1,49]}=8.0, p=0.007\right) . \delta^{13} \mathrm{C}$ differences between muscle tissue and the eye lens ranged from -1.7 to 7.8 (Fig. 6 ). $\delta^{15} \mathrm{~N}$ differences between muscle tissue and the eye lens ranged from -3.8 to 0.5 . Mean muscle $\delta^{13} \mathrm{C}$ values were $\sim 2.37 \%$ more depleted than the eye lens (mean \pm standard error: $-2.37 \% \pm 0.3 \%$ ), with only five individuals with muscle more enriched than the eye lens. $\delta^{15} \mathrm{~N}$ values from muscle tissue were $\sim 1.78 \%$ more enriched than the eye lens $(1.78 \% \pm 0.2 \%)$, and only three individuals had muscle more depleted than the eye lens. Variability between muscle and eye lens isotopes was highest for smaller fish ( $<200 \mathrm{~mm} \mathrm{SL})$. We tested for associations of muscle-eye lens variability with other measured parameters (C:N atomic ratios of the respective tissues, capture region, and natal origin), with no significant results $(p>0.8)$. Due to mechanistic uncertainty regarding cause of muscle-eye lens variability for 
Fig. 5. Stable isotope values (A: carbon, B: nitrogen) for left (grey points-lines) and right (black points-lines) eye lenses of individual Clear Lake hitch identified by sample number. There were no significant differences between left and right eye lenses $\left(\mathrm{ANCOVA} ; \delta^{13} \mathrm{C}\right.$ : $\left.p=0.89 ; \delta^{15} \mathrm{~N}: p=0.94\right)$.

A

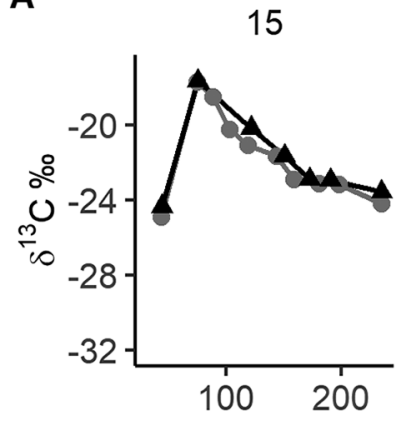

21

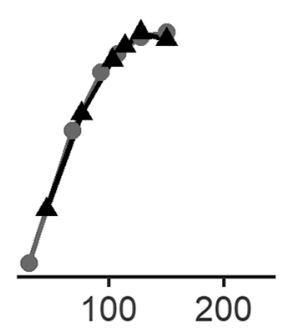

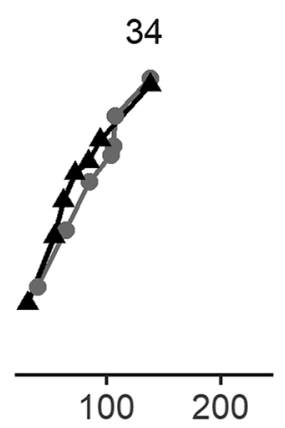

B

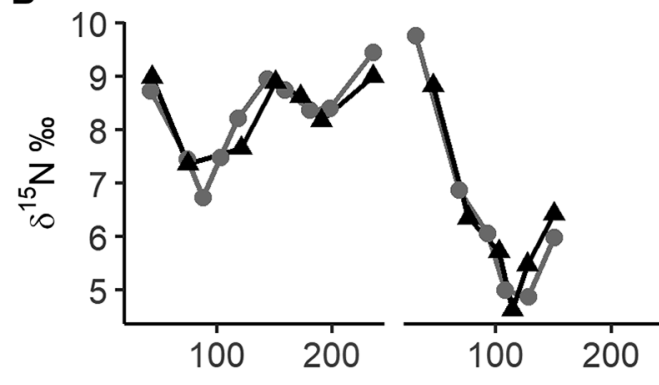

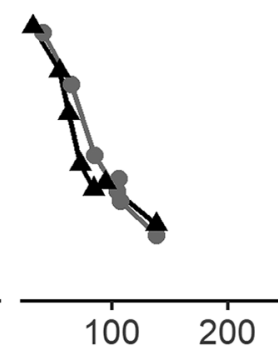

39
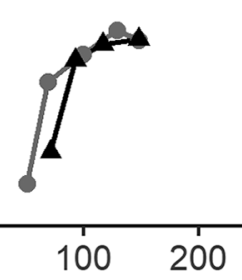

43

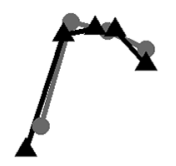

100200
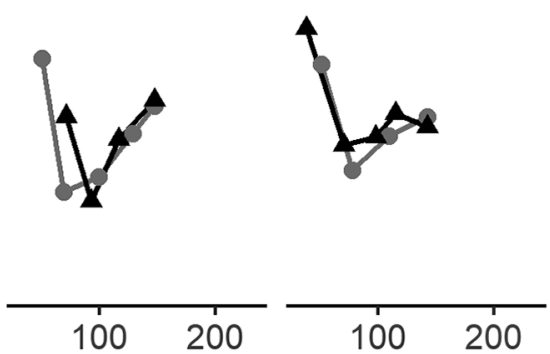

46

\section{Standard Length $(\mathrm{mm})$}

smaller fish we added mean and standard deviation of muscle eye lens differences to muscle fractionation values (see Materials and methods), thus retaining uncertainty within the modeling framework.

\subsection{Identification of ontogenetic habitat shifts}

Clear Lake hitches exhibited shifts in prey consumption across ontogeny based on mixing model results (Fig. 7A). Smaller individuals generally consumed benthic prey items and larger individuals consumed pelagic prey items. For an average individual, the shift from benthic to pelagic prey is inferred to have started at approximately $84 \mathrm{~mm} \mathrm{SL}$, where pelagic prey items comprise $10 \%$ of the diet. Pelagic prey items comprise a majority (>50\%) of the diet at approximately $158 \mathrm{~mm} \mathrm{SL}$, and benthic prey are largely absent from the diet (pelagic prey $>90 \%$ ) at $232 \mathrm{~mm}$ SL. Model results using eye lens and muscle data were generally consistent, with median values from the muscle model following within credible intervals outlined by the eye lens model results (Fig. 7A). The muscle model took longer to converge and had wider credible intervals, likely related to fewer data points. For larger fish, musclebased results suggested a smaller proportion of pelagic prey than lens-based results, although there was reciprocal overlap in median values from one model and credible intervals for the other model. For smaller fish, muscle and lens-based results were nearly identical.

Although model results indicated generalized ontogenetic size cutoffs, there was high variability across individual fishes, with certain individuals shifting to pelagic prey at different sizes or not at all (Fig. 7B; also refer to online Supplementary Data, Table $S 1^{1}$ ). Fourteen individuals never reached a median modeled diet of $10 \%$ pelagic prey. Each of these individuals was a juvenile between 138 and $170 \mathrm{~mm}$ SL. Five individuals were always above the $90 \%$ pelagic prey threshold, and their lengths ranged from 145 to $240 \mathrm{~mm}$ SL. For the remaining fish which exhibited shifts from benthic to pelagic prey, standard lengths at which the $50 \%$ pelagic diet threshold was reached varied from 65 to $295 \mathrm{~mm}$ SL. There were no observed relationships between the size at which a fish crossed the $50 \%$ pelagic diet threshold and capture region within Clear Lake (ANOVA results: $F_{[2,17]}=0.76, p=0.48$ ) and stream natal origin $\left(\mathrm{F}_{[3,15]}=0.81, p=0.51\right.$; Supplementary Data, Fig. $\left.S 1^{1}\right)$.

\section{Discussion}

\subsection{Eye lenses and recreating trophic histories}

With this study we were able to successfully apply eye lensbased isotopic analysis to recreate size-calibrated isotopic histories for individual fish. We were thus able to identify important ontogenetic habitat shifts and glean insight into ecological processes that were unavailable with other archival tissues and chemical markers (Feyrer et al. 2019a). Due to the relatively novel nature of this approach we needed to address key uncertainties potentially limiting the use of eye lens proteins as accurate recorders of lifetime stable isotope histories: the species-specific relationship between lens size and fish size, the relationship between lens protein stable isotope composition and conventional tissues like white muscle, and the consistency of isotopic patterns within and among individuals (Quaeck-Davies et al. 2018). Each of these uncertainties was addressed for Clear Lake hitch.

Clear Lake hitches exhibited a strong relationship between lens size and fish size, a relationship that has been documented for other fish species (Quaeck-Davies et al. 2018; Simpson et al.

\footnotetext{
${ }^{1}$ Supplementary data are available with the article at https://doi.org/10.1139/cjfas-2020-0318.
} 
Fig. 6. The difference between eye lens and muscle stable isotope values (A: carbon, B: nitrogen), calculated as $\delta^{X}$ Yeye $-\delta^{X}$ Ymuscle plotted against fish size for Clear Lake hitch. Eye lens values are a weighted average of the three outermost eye lens layers.
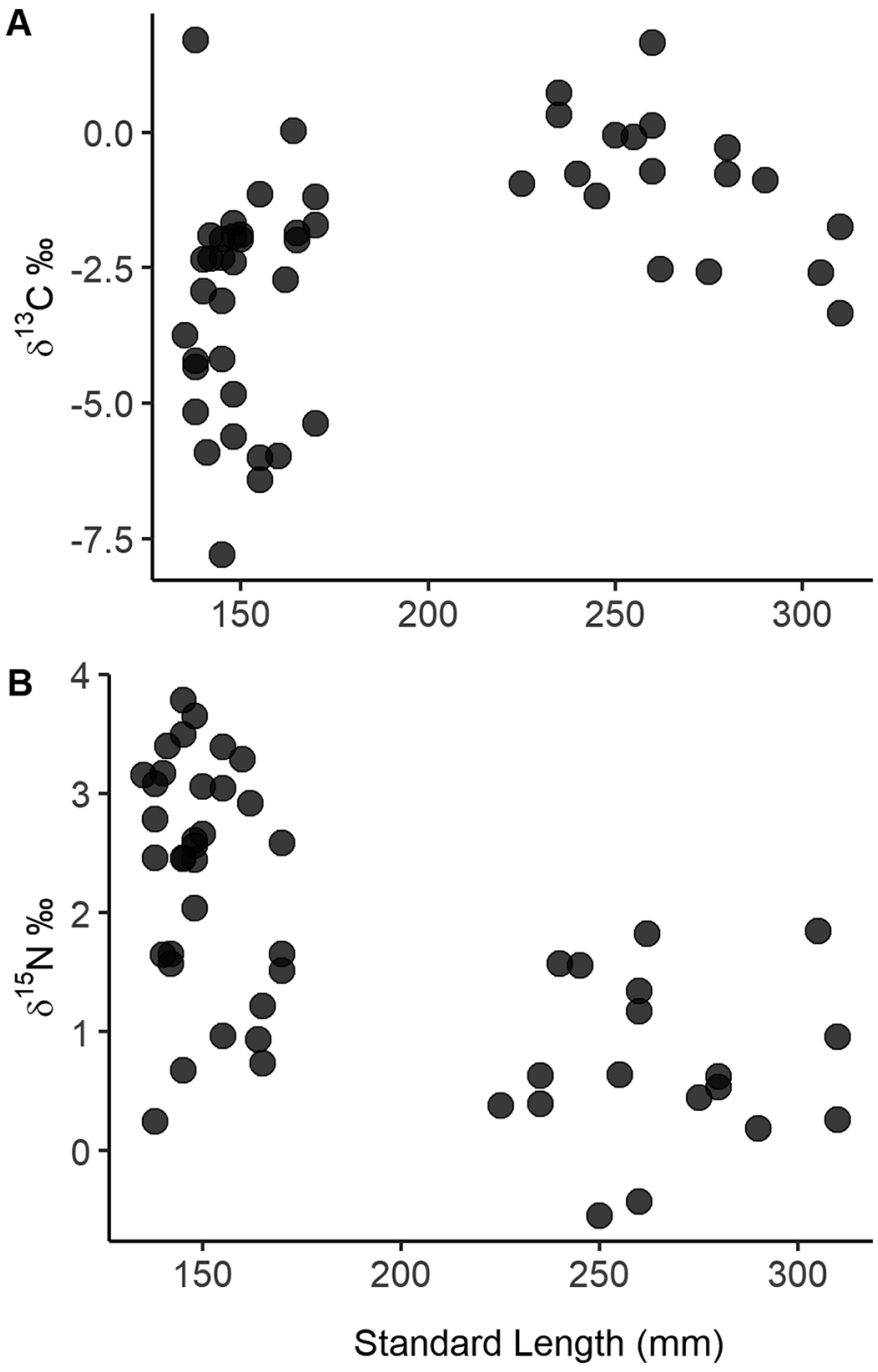

2019; Curtis et al. 2020; Bell-Tilcock et al. 2021, Vecchio et al. 2021) but is an essential prerequisite for subsequent inference. Measured variability in eye lens size relative to fish size was low, including the early juvenile fishes encompassed in this analysis. It is, however, still possible that the relationship between fish size and eye lens size scales differently during early growth, although Bell-Tilcock et al. (2021) observed a linear relationship in juvenile Chinook salmon (Oncorhynchus tshawytscha). We observed significant differences in the isotopic composition of eye lens and muscle tissues, although similar to other studies (Quaeck-Davies et al. 2018; Simpson et al. 2019) variability in eye lenses was higher than muscle tissue. It is unclear what drives this variability, although it may have to do with differences in tissue turnover rates, particularly across different fish sizes (Weidel et al. 2011). Note that juvenile Clear Lake hitches exhibited higher variability in the difference between eye lenses and muscle tissue.

Size-specific fractionation has been observed for other fish tissues, but the magnitude is typically small across size classes $(<1 \%$; Sweeting et al. 2007) and affected by lipid content (Mohan et al. 2016). Given the large variability observed in this study and the low lipid content of both eye lenses (Wallace et al. 2014) and sampled muscle tissue $(\mathrm{C}: \mathrm{N}<3.5)$, variability in discrepancies between eye lens and muscle values likely reflect differences in tissue turnover timing. This could mean longer or shorter incorporation times for eye lenses with respect to muscle tissue, or simply reflect the difficulty of matching up the time scales represented by different tissue types. Estimates of eye lens tissue turnover from Granneman (2018) range between 30 and 71 days (mean $\sim 55$ days). Although this is somewhat similar to muscle tissue turnover times, it is difficult to identify the temporal window represented by a particular lamina for individuals where age is not precisely known. Regardless, further evaluation of tissuespecific fractionation and the time scales of incorporation during the formation of eye lens tissues is warranted. Within-individual variability in eye lens protein stable isotopes was low, as left and right eye lenses had similar isotope values; this result is consistent with other studies (Wallace et al.2014). This suggests that the isotopic trajectories observed within an eye lens are reproducible and likely due to diet conditions during eye lens formation. Although within-individual isotopic variability was low, variability of size-calibrated isotopic histories across individuals was high. This resulted in variability in modeled size at habitat shift and could reflect a variety of factors, explored below.

In addition to addressing the validation needs specified by Quaeck-Davies et al. (2018), we also determined that trophic habitat inferred from eye lens analysis was qualitatively similar to trophic habitat inferred from muscle tissue analysis. Consistent model results between the two tissue types suggest that estimated tissue-specific offsets and the modeling approach are sound.

\subsection{Individual variability and ecological inference}

In this study we detected no relationship between individual variability in size at trophic habitat shift and metrics such as lake region or natal origin. This observed variability could reflect other drivers of ontogenetic habitat shifts, including interannual differences in local productivity (Eagles-Smith et al. 2008b), predation pressure (Werner et al. 1983; Werner and Hall 1988), or some other metric of habitat suitability. For example, movement from juvenile to adult habitat types often represents an explicit behavioral response to changes in predation risk as a function of body size, with smaller individuals more tightly tied to habitats that minimize mortality risk and then shift to more productive, risky habitats when the potential for growth or other benefit outweighs the risk (Werner and Gilliam 1984; Dahlgren and Eggleston 2000). Local differences in predator density, habitat type, or food availability may therefore mediate the size or timing of offshore ontogenetic migrations by Clear Lake hitches (e.g., offshore migration occurring earlier in areas with high littoral predator density).

Alternately, our sample size may have been insufficient to suitably describe Clear Lake hitch life history variability. Of the 46 collected individuals allowed by state permitting requirements, 29 had a standard length less than $175 \mathrm{~mm}$. Based on published length at age information (Geary and Moyle 1980), these individuals were less than three years old and likely not yet reproductively active. Many of these subadult individuals did not display the same lifetime trends as adult fish, likely because many of them may not have completed their migration to pelagic habitats. Further analyses of fish collected in subsequent years and other habitats is necessary to fully describe the variability in limnetic Clear Lake hitch habitat use. Individual and withinpopulation variability in habitat use can be an important factor influencing population stability (Bolnick et al. 2003) and is common in fishes (e.g., Bryan and Larkin 1972; Vander Zanden et al. 2000).

It also should be noted that our current understanding of Clear Lake food webs may be dated, as it is based on earlier literature (Eagles-Smith et al. 2008a, 2008b). Although unlikely that basal 
Fig. 7. Panel A shows the proportion of different prey guilds to Clear Lake hitch as a function of fish size. Solid coloured lines represent median values from eye lens mixing model results, and shaded ribbons represent $95 \%$ credible intervals around the median value. Gray bars and points represent median values and $95 \%$ credible intervals from muscle mixing model results. Diet thresholds of $10 \%, 50 \%$, and $90 \%$ based on eye lens model results are shown, along with corresponding fish standard length. Panel B shows individual variation in pelagic diet proportion based on eye lens model results. Global median and 95\% credible interval values are denoted by thick solid line and shaded ribbon (same colours as panel A), and individual fishes $(n=44)$ represented by thin lines and transparent points. [Colour online.]
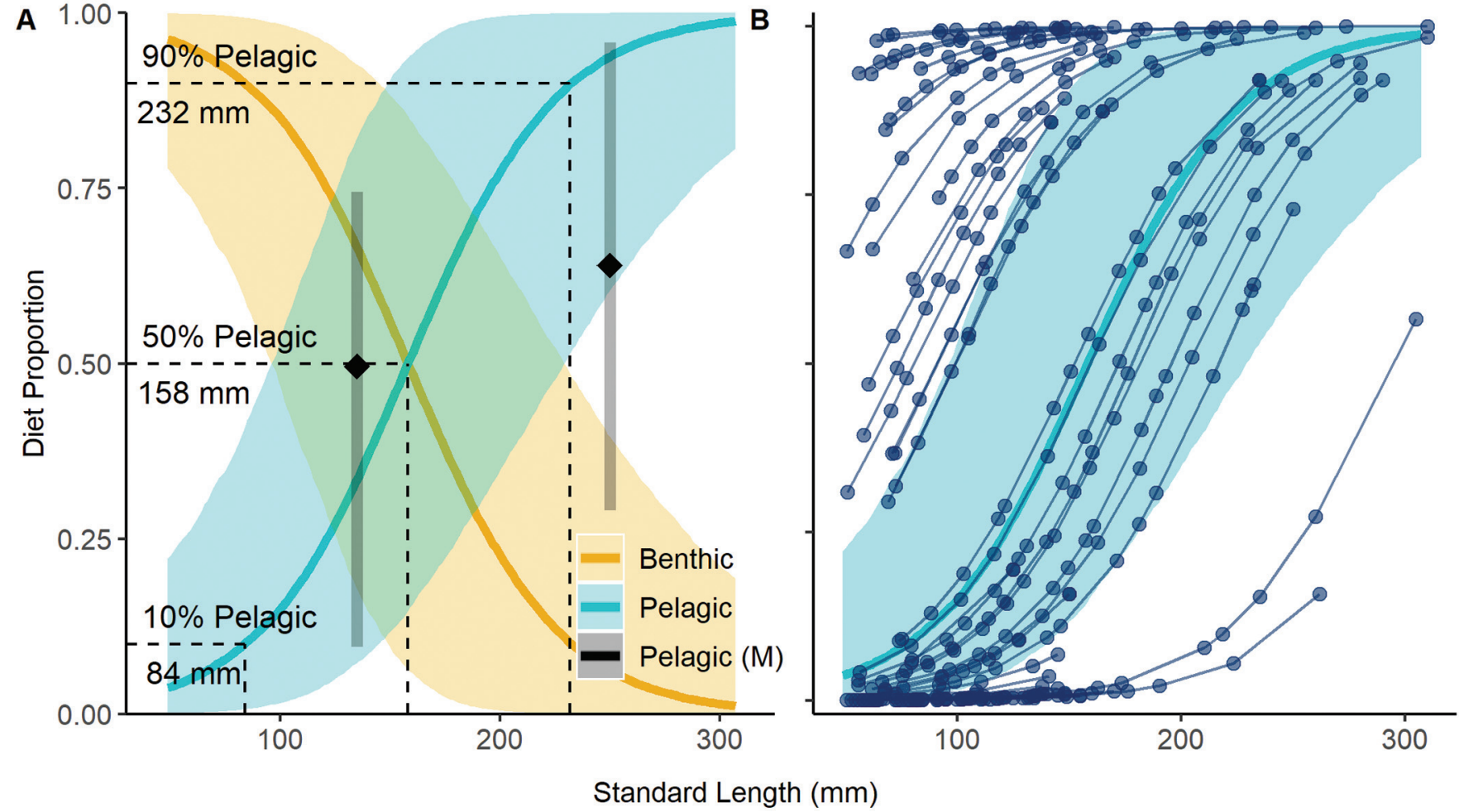

carbon signatures would change dramatically, a holistic evaluation of contemporary local food webs is necessary for more detailed food web characterization. Updated food web characterization could provide better resolution for prey consumption by Clear Lake hitches, including corroboration of trophic habitat, identification of specific prey items and evaluation of competition with introduced species. Introduced zooplanktivores (primarily threadfin shad, Dorosoma petenense) can heavily reduce pelagic prey availability in Clear Lake (Eagles-Smith et al. 2008a). Data on recent threadfin shad abundance are non-existent, but it is plausible that variability in threadfin shad abundance could influence the ontogenetic timing of Clear Lake hitch habitat shifts and thus mediate the exposure of Clear Lake hitches to littoral predators. Largemouth bass (Micropterus salmoides) and other non-native predators in Clear Lake are postulated to contribute to population declines of the Clear Lake hitch and other native fishes (Thompson et al. 2013).

\subsection{Updates to current life history understanding and management implications}

The general potamodromous life history of the Clear Lake hitch has been understood for decades (Moyle 2002), with adults spawning in tributaries, juveniles outmigrating to the lake's littoral zone, and eventual offshore migration into pelagic habitats. However, the size at which fish make these habitat migrations has only been estimated from physical capture of individuals. Previous estimates of offshore migration of juvenile Clear Lake hitches were between 40 and $50 \mathrm{~mm}$ SL. These estimates fall within the range of values observed in this study, but these previous estimates suggest that Clear Lake hitches use littoral habitats less frequently than we observed. Feyrer et al. (2019b) observed that juvenile fishes less than $175 \mathrm{~mm}$ SL were more abundant in littoral habitats, a finding consistent with our estimates of migration size. It is possible that Clear Lake hitches may spend time in pelagic habitats at smaller sizes than found in this study, but with foraging primarily nearshore. Pairing SIA in eye lenses with field observations would allow the decoupling of fish presence with an individual's feeding ecology. This study's observed pelagic trophic habitat use may not completely align with other habitat uses, such as the potential for pelagic refuge from nearshore predation.

It is also important to note that these previous estimates of size at habitat shift were made prior to several dramatic ecological changes to the Clear Lake ecosystem. The introductions of Mississippi silverside (Menidia audens; introduced to Clear Lake in 1967) and threadfin shad (introduced in 1985; Thompson et al. 2013) are known to heavily impact local fishes (e.g., Li et al. 1976; Moyle and Holzhauser 1978) and have heavily altered lake food webs as local populations fluctuate (Eagles-Smith et al. 2008a). Our updated estimate $(\sim 160 \mathrm{~mm} \mathrm{SL})$ may reflect changes to pelagic productivity, type or availability of littoral habitat, or other environmental changes. For example, competition with pelagic threadfin shad may result in individual hitch staying nearshore for longer. If true, this potentially delayed offshore migration may result in increased exposure of juvenile Clear Lake hitch to predation from nearshore predators, particularly largemouth bass.

Current monitoring of the Clear Lake hitch population is limited due to geographic scope and the rarity of encounters. In this study the use of eye lens stable isotopes allowed for reconstruction of individual trophic trajectories for Clear Lake hitches, and, 
when coupled with analysis of other tissues, allowed for the reconstruction of virtually the entire life history trajectory of each individual fish, from natal origin to adult habitat use. These individual trajectories identify ages and (or) sizes at which notable migratory or trophic positions take place, which informs the identification and prioritization of critical habitat for at-risk species. Similarly, these trajectories indicate information about the general life history of a rare species and highlight the diversity and behavioral plasticity exhibited by that species that may be important for population resilience. This type of data is highly valuable to scientists and managers tasked with conserving listed taxa and informs the management and preservation of the Clear Lake hitch.

\section{Contributor's statement}

MY and FF conceived and designed the research; MT and GW assisted with methodological development; VL and JC analyzed samples; MY analyzed the data; MY, FF, VL, JC, MT, GW and RJ wrote the manuscript.

\section{Acknowledgements}

D. Ayers, E. Clark, M.J. Farruggia, E. Gusto, O. Patton and D. Steinke assisted with field work. Emerson Gusto provided the graphics for the conceptual model in Fig. 1. Larry Brown and Brock Huntsman provided advice, feedback, and stimulating conversation. Comments from Theodore Kennedy and anonymous reviewers greatly improved the manuscript. Funding was provided by the US Fish and Wildlife Service and US Geological Survey. Take of Clear Lake hitch for this study was permitted under a Scientific Collection Permit (SC-3602) and an associated Memorandum of Understanding issued by the California Department of Fish and Wildlife. Any use of trade, firm, or product names is for descriptive purposes only and does not imply endorsement by the US Government.

\section{References}

Bassnett, S., and Beebe, D.C. 1992. Coincident loss of mitochondria and nuclei during lens fiber cell differentiation. Dev. Dyn. 194(2): 85-93. doi:10.1002/ aja.1001940202. PMID:1421526.

Baumsteiger, J., and Moyle, P.B. 2019. A reappraisal of the California roach/ hitch (Cypriniformes, Cyprinidae, Hesperoleucus/Lavinia) species complex. Zootaxa, 4543(2): 221-240. doi:10.11646/zootaxa.4543.2.3. PMID:30647303.

Baumsteiger, J., Young, M., and Moyle, P.B. 2019. Using the distinct population segment (DPS) concept to protect fishes with low levels of genomic differentiation: conservation of an endemic minnow (Hitch). Trans. Am. Fish. Soc. 148(2): 406-416. doi:10.1002/tafs.10144.

Bell-Tilcock, M., Jeffres, C.A., Rypel, A.L., Sommer, T.R., Katz, J.V., Whitman, G.E., and Johnson, R.C. 2021. Advancing diet reconstruction in fish eye lenses. Methods Ecol. Evol. 12: 449-457. doi:10.1111/2041-210X.13543.

Block, B.A., Dewar, H., Blackwell, S.B., Williams, T.D., Prince, E.D., Farwell, C.J., et al. 2001. Migratory movements, depth preferences, and thermal biology of Atlantic bluefin tuna. Science, 293(5533): 1310-1314. doi:10.1126/science.1061197. PMID:11509729.

Bloemendal, H., de Jong, W., Jaenicke, R., Lubsen, N.H., Slingsby, C., and Tardieu, A. 2004. Ageing and vision: structure, stability and function of lens crystallins. Prog. Biophys. Mol. Biol. 86(3): 407-485. doi:10.1016/j. pbiomolbio.2003.11.012. PMID:15302206.

Bolnick, D.I., Svanbäck, R., Fordyce, J.A., Yang, L.H., Davis, J.M., Hulsey, C.D., and Forister, M.L. 2003. The ecology of individuals: incidence and implications of individual specialization. Am. Nat. 161(1): 1-28. doi:10.1086/343878. PMID: 12650459.

Bron, A., Vrensen, G., Koretz, J., Maraini, G., and Harding, J. 2000. The ageing lens. Ophthalmologica, 214(1): 86-104. doi:10.1159/000027475. PMID:10657747.

Bryan, J.E., and Larkin, P. 1972. Food specialization by individual trout. J. Fish. Res. Bd. Can. 29(11): 1615-1624. doi:10.1139/f72-248.

Campana, S.E. 1999. Chemistry and composition of fish otoliths: pathways, mechanisms and applications. Mar. Ecol. Prog. Ser. 188: 263-297. doi:10.3354| meps188263.

Clemens, B.J., Binder, T.R., Docker, M.F., Moser, M.L., and Sower, S.A. 2010. Similarities, differences, and unknowns in biology and management of three parasitic lampreys of North America. Fisheries, 35(12): 580-594. doi:10.1577| 1548-8446-35.12.580.
Curtis, J.S., Albins, M.A., Peebles, E.B., and Stallings, C.D. 2020. Stable isotope analysis of eye lenses from invasive lionfish yields record of resource use. Mar. Ecol. Prog. Ser. 637: 181-194. doi:10.3354/meps13247.

Dahlgren, C.P., and Eggleston, D.B. 2000. Ecological processes underlying ontogenetic habitat shifts in a coral reef fish. Ecology, 81(8): 2227-2240. doi:10.1890/0012-9658(2000)081[2227:EPUOHS]2.0.CO;2.

Dahm, R., Schonthaler, H.B., Soehn, A.S., Van Marle, J., and Vrensen, G.F. 2007. Development and adult morphology of the eye lens in the zebrafish. Exp. Eye Res. 85(1): 74-89. doi:10.1016/j.exer.2007.02.015. PMID:17467692.

Dove, S., and Kingsford, M. 1998. Use of otoliths and eye lenses for measuring trace-metal incorporation in fishes: a biogeographic study. Mar. Biol. 130(3): 377-387. doi:10.1007/s002270050258.

Eagles-Smith, C.A., Suchanek, T.H., Colwell, A.E., and Anderson, N.L. $2008 a$. Mercury trophic transfer in a eutrophic lake: the importance of habitatspecific foraging. Ecol. Appl. 18(sp8): A196-A212. doi:10.1890/06-1476.1. PMID:19475925.

Eagles-Smith, C.A., Suchanek, T.H., Colwell, A.E., Anderson, N.L., and Moyle, P.B. 2008b. Changes in fish diets and food web mercury bioaccumulation induced by an invasive planktivorous fish. Ecol. Appl. 18(sp8): A213-A226. doi:10.1890/06-1415.1. PMID:19475926.

Feyrer, F.V. 2018. Clear Lake Hitch Otolith Data. US Geological Survey. doi:10.5066/P9IX7L5V.

Feyrer, F. 2019. Observations of the spawning ecology of the imperiled Clear Lake Hitch Lavinia exilicauda chi. California Fish and Game, 105(4): 225232

Feyrer, F., Whitman, G., Young, M., and Johnson, R.C. 2019a. Strontium isotopes reveal ephemeral streams used for spawning and rearing by an imperilled potamodromous cyprinid Clear Lake hitch Lavinia exilicauda chi. Mar. Freshwater Res. 70: 1689. doi:10.1071/MF18264.

Feyrer, F., Young, M., Patton, O., and Ayers, D. 2019b. Dissolved oxygen controls summer habitat of Clear Lake Hitch (Lavinia exilicauda chi), an imperilled potamodromous cyprinid. Ecol. Freshwater Fish, 29: 188-196. doi:10.1111/eff.12505.

Geary, R.E., and Moyle, P.B. 1980. Aspects of the ecology of the hitch, Lavinia exilicauda (Cyprinidae), a persistent native cyprinid in Clear Lake, California. Southwest. Nat. 25: 385-390. doi:10.2307/3670695.

Geary, R.E. 1978. Life history of the Clear Lake Hitch (Lavinia Exilucauda Chi). M.S. thesis, University of California, Davis, Calif.

Granneman, J.E. 2018. Evaluation of trace-metal and isotopic records as techniques for tracking lifetime movement patterns in fishes. Thesis, University of South Florida.

Hawes, S., Miskiewicz, T., Garcia, V., and Figueira, W. 2020. Size and stagedependent vertical migration patterns in reef-associated fish larvae off the eastern coast of Australia. Deep Sea Res. Part I Oceanogr. Res. Pap. 164: 103362. doi:10.1016/j.dsr.2020.103362.

Hunsicker, M.E., Essington, T.E., Aydin, K.Y., and Ishida, B. 2010. Predatory role of the commander squid Berryteuthis magister in the eastern Bering Sea: Insights from stable isotopes and food habits. Mar. Ecol. Prog. Ser. 415: 91-108. doi:10.3354/meps08750.

Ingram, B.L., and Weber, P.K. 1999. Salmon origin in California's SacramentoSan Joaquin river system as determined by otolith strontium isotopic composition. Geology, 27(9): 851-854. doi:10.1130/0091-7613(1999)027<0851: SOICSS $>2.3$. CO; 2 .

Johnson, R.C., Stewart, A.R., Limburg, K.E., Huang, R., Cocherell, D., and Feyrer, F. 2020. Lifetime chronicles of selenium exposure linked to deformities in an imperiled migratory fish. Environ. Sci. Technol. 54(5): 2892-2901. doi:10.1021/ acs.est.9b06419. PMID:32088956.

Kingsford, M., and Gillanders, B. 2000. Variation in concentrations of trace elements in otoliths and eye lenses of a temperate reef fish, Parma microlepis, as a function of depth, spatial scale, and age. Mar. Biol. 137(3): 403-414. doi:10.1007/s002270000304.

Kurth, B.N., Peebles, E.B., and Stallings, C.D. 2019. Atlantic Tarpon (Megalops atlanticus) exhibit upper estuarine habitat dependence followed by foraging system fidelity after ontogenetic habitat shifts. Estuar. Coast. Shelf Sci. 225: 106248. doi:10.1016/j.ecss.2019.106248.

Li, H.W., Moyle, P.B., and Garrett, R.L. 1976. Effect of the introduction of the Mississippi silverside (Menidia audens) on the growth of black crappie (Pomoxis nigromaculatus) and white crappie (P. annularis) in Clear Lake, California. Trans. Am. Fish. Soc. 105(3): 404-408. doi:10.1577/1548-8659(1976) 105\%3C404:EOTIOT\%3E2.0.CO;2.

Limburg, K.E., Walther, B.D., Lu, Z., Jackman, G., Mohan, J., Walther, Y., et al. 2015. In search of the dead zone: use of otoliths for tracking fish exposure to hypoxia. J. Mar. Syst. 141: 167-178. doi:10.1016/j.jmarsys.2014.02.014.

Liu, B.L., Xu, W., Chen, X.J., Huan, M.Y., and Liu, N. 2020. Ontogenetic shifts in trophic geography of jumbo squid, Dosidicus gigas, inferred from stable isotopes in eye lens. Fish. Res. 226: 105507. doi:10.1016/j.fishres.2020.105507.

Maciej Gliwicz, Z., Slon, J., and Szynkarczyk, I. 2006. Trading safety for food: evidence from gut contents in roach and bleak captured at different distances offshore from their daytime littoral refuge. Freshwater Biol. 51(5): 823-839. doi:10.1111/j.1365-2427.2006.01530.x.

McCutchan, J.H., Lewis, W.M., Kendall, C., and McGrath, C.C. 2003. Variation in trophic shift for stable isotope ratios of carbon, nitrogen, and sulfur. Oikos, 102(2): 378-390. doi:10.1034/j.1600-0706.2003.12098.x.

Meath, B., Peebles, E.B., Seibel, B.A., and Judkins, H. 2019. Stable isotopes in the eye lenses of Doryteuthis plei (Blainville 1823): Exploring natal origins 
and migratory patterns in the eastern Gulf of Mexico. Cont. Shelf Res. 174: 76-84. doi:10.1016/j.csr.2018.12.013.

Mohan, J.A., Smith, S.D. Connelly, T.L., Attwood, E.T., McClelland, J.W. Herzka, S.Z., and Walther, B.D. 2016. Tissue-specific isotope turnover and discrimination factors are affected by diet quality and lipid content in an omnivorous consumer. J. Exp. Mar. Biol. Ecol. 479: 35-45. doi:10.1016/j. jembe.2016.03.002.

Moyle, P.B. 2002. Inland fishes of California: revised and expanded. University of California Press, Berkeley, Calif.

Moyle, P.B., and Holzhauser, N.J. 1978. Effects of the introduction of Mississippi silverside (Menidia audens) and Florida largemouth bass (Micropterus salmoides floridanus) on the feeding habits of young-of-year largemouth bass in Clear Lake, California. Trans. Am. Fish. Soc. 107(4): 574-582. doi:10.1577| 1548-8659(1978)107<574:EOTIOM>2.0.CO;2.

Moyle, P.B., Kiernan, J.D., Crain, P.K., and Quinones, R.M. 2013. Climate change vulnerability of native and alien freshwater fishes of California: a systematic assessment approach. PLoS One, 8(5): e63883. doi:10.1371/journal. pone.0063883. PMID:23717503.

Nicol, J.A.C., and Somiya, H. 1989. The eyes of fishes. Oxford University Press, Oxford, UK.

OCM Partners. 2021. 2015-2016 Lake County, California Lidar; Classified Point Cloud. From 2010-06-15 to 2010-08-15. NOAA National Centers for Environmental Information. Available from https://www.fisheries.noaa. gov/inport/item/55316.

Parry, M.P. 2003. The trophic ecology of two ommastrephid squid species, Ommastrephes bartramii and Sthenoteuthis oualaniensis, in the north Pacific sub-tropical gyre. Ph.D. dissertation, University of Hawaii at Manoa. Available from http://hdl.handle.net/10125/3068.

Peebles, E.B., and Hollander, D.J. 2020. Combining isoscapes with tissue-specific isotope records to recreate the geographic histories of fish. In Scenarios and Responses to Future Deep Oil Spills. Springer. pp. 203-218. doi:10.1007/978-3-030-12963-7_12.

Phillips, D.L., Inger, R., Bearhop, S., Jackson, A.L., Moore, J.W., Parnell, A.C., et al. 2014. Best practices for use of stable isotope mixing models in foodweb studies. Can. J. Zool. 92(10): 823-835. doi:10.1139/cjz-2014-0127.

Post, D.M., Layman, C.A., Arrington, D.A., Takimoto, G., Quattrochi, J., and Montana, C.G. 2007. Getting to the fat of the matter: Models, methods and assumptions for dealing with lipids in stable isotope analyses. Oecologia, 152(1): 179-189. doi:10.1007/s00442-006-0630-x.

Quaeck-Davies, K., Bendall, V.A., MacKenzie, K.M., Hetherington, S., Newton, J., and Trueman, C.N. 2018. Teleost and elasmobranch eye lenses as a target for life-history stable isotope analyses. Peer], 6: e4883. doi:10.7717/peerj.4883. PMID:29888128.

R Core Team. 2019. R: a language and environment for statistical computing. R Foundation for Statistical Computing. Available from https:/|www.R-project. org/.

Richerson, P.J., Suchanek, T.H., Zierenberg, R.A., Osleger, D.A., Heyvaert, A.C., Slotton, D.G., et al. 2008. Anthropogenic stressors and changes in the Clear Lake ecosystem as recorded in sediment cores. Ecol. Appl. 18(8): A257-A283. doi:10.1890/06-1458.1. PMID:19475929.

Runge, C.A., Martin, T.G., Possingham, H.P., Willis, S.G., and Fuller, R.A. 2014. Conserving mobile species. Front. Ecol. Environ. 12(7): 395-402. doi:10.1890| 130237.

Secor, D.H., Henderson-Arzapalo, A., and Piccoli, P. 1995. Can otolith microchemistry chart patterns of migration and habitat utilization in anadromous fishes? J. Exp. Mar. Biol. Ecol. 192(1): 15-33. doi:10.1016/0022-0981 (95)00054-U

Simpson, S.J., Sims, D.W., and Trueman, C.N. 2019. Ontogenetic trends in resource partitioning and trophic geography of sympatric skates (Rajidae) inferred from stable isotope composition across eye lenses. Mar. Ecol. Prog. Ser. 624: 103-116. doi:10.3354/meps13030.

Steinke, D.A., Young, M.J., and Feyrer, F.V. 2019. Abundance and distribution of fishes in Clear Lake, Lake County, California (ver. 2.0). US Geological Survey. doi:10.5066/P9A03OI6.
Steinke, D.A., Young, M.J., and Feyrer, F.V. 2020. Isotopic analysis of Clear Lake Hitch collected from Clear Lake, Lake County, California, 2017. US Geological Survey. doi:10.5066/P98S3SBV.

Stock, B., and Semmens, B. 2016. MixSIAR User Manual. Version 3, 1.

Stock, B.C., Jackson, A.L., Ward, E.J., Parnell, A.C., Phillips, D.L., and Semmens, B.X. 2018. Analyzing mixing systems using a new generation of Bayesian tracer mixing models. PeerJ, 6: e5096. doi:10.7717/peerj.5096. PMID:29942712.

Suchanek, T.H., Richerson, P., Nelson, D., Eagles-Smith, C., Anderson, D., Cech, J.J., et al. 2003. Evaluating and managing a multiply stressed ecosystem at Clear Lake, California: a holistic ecosystem approach. In Managing for Healthy Ecosystems: Case Studies. Vol. 1239. ROUTLEDGE in association with GSE Research. pp. 1239-1271. CRC Press. ISBN: 9780429143236.

Suchanek, T.H., Eagles-Smith, C.A., Slotton, D.G., Harner, E.J., Adam, D.P. Colwell, A.E., et al. 2008. Mine-derived mercury: effects on lower trophic species in Clear Lake, California. Ecol. Appl. 18(sp8): A158-A176. doi:10.1890/ 06-1485.1. PMID:19475923.

Suchanek, T.H., Cooke, J., Keller, K., Jorgensen, S., Richerson, P.J., Eagles-Smith, C.A., et al. 2009. A mass balance mercury budget for a mine-dominated lake: Clear Lake, California. Water Air Soil Pollut. 196(1-4): 51-73. doi:10.1007/s11270-0089757-1.

Sweeting, C., Barry, J., Polunin, N., and Jennings, S. 2007. Effects of body size and environment on diet-tissue $\delta^{13} \mathrm{C}$ fractionation in fishes. J. Exp. Mar. Biol. Ecol. 352(1): 165-176. doi:10.1016/j.jembe.2007.07.007.

Swift, C. 1965. Early development of the hitch, Lavinia exilicauda, of Clear Lake, California. California Fish and Game, 51: 74-80. doi:10.2307/3670695.

Thompson, L.C., Giusti, G.A., Weber, K.L., and Keiffer, R.F. 2013. The native and introduced fishes of Clear Lake: a review of the past to assist with decisions of the future. California Fish and Game, 99(1): 7-41.

Tzadik, O.E., Curtis, J.S., Granneman, J.E., Kurth, B.N., Pusack, T.J., Wallace, A.A., et al. 2017. Chemical archives in fishes beyond otoliths: a review on the use of other body parts as chronological recorders of microchemical constituents for expanding interpretations of environmental, ecological, and life-history changes. Limnol. Oceanogr. Methods, 15(3): 238-263. doi:10.1002/lom3.10153.

Vander Zanden, M.J., Shuter, B.J., Lester, N.P., and Rasmussen, J.B. 2000. Within-and among-population variation in the trophic position of a pelagic predator, lake trout (Salvelinus namaycush). Can. J. Fish. Aquat. Sci. 57(4): 725731. doi:10.1139/f00-011.

Vander Zanden, M.J., Clayton, M.K., Moody, E.K., Solomon, C.T., and Weidel, B.C. 2015. Stable isotope turnover and half-life in animal tissues: a literature synthesis. PLoS ONE, 10(1): e0116182. doi:10.1371/journal.pone.0116182. PMID:25635686.

Vecchio, J.L., and Peebles, E.B. 2020. Spawning origins and ontogenetic movements for demersal fishes: an approach using eye-lens stable isotopes. Estuar. Coast. Shelf Sci. 246: 107047. doi:10.1016/j.ecss.2020.107047.

Vecchio, J.L., Ostroff, J.L., and Peebles, E.B. 2021. Isotopic characterization of lifetime movement by two demersal fishes from the northeastern Gulf of Mexico. Mar. Ecol. Prog. Ser. 657: 161-172. doi:10.3354/meps13525.

Wallace, A.A., Hollander, D.J., and Peebles, E.B. 2014. Stable isotopes in fish eye lenses as potential recorders of trophic and geographic history. PLoS ONE, 9(10): e108935. doi:10.1371/journal.pone.0108935. PMID:25279946.

Weidel, B.C., Carpenter, S.R., Kitchell, J.F., and Vander Zanden, M.J. 2011. Rates and components of carbon turnover in fish muscle: insights from bioenergetics models and a whole-lake ${ }^{13} \mathrm{C}$ addition. Can. J. Fish. Aquat. Sci. 68(3): 387-399. doi:10.1139/F10-158.

Werner, E.E., and Gilliam, J.F. 1984. The ontogenetic niche and species interactions in size-structured populations. Annu. Rev. Ecol. Syst. 15(1): 393425. doi:10.1146/annurev.es.15.110184.002141.

Werner, E.E., and Hall, D.J. 1988. Ontogenetic habitat shifts in bluegill: the foraging rate-predation risk trade-off. Ecology, 69(5): 1352-1366. doi:10.2307| 1941633

Werner, E.E., Gilliam, J.F., Hall, D.J., and Mittelbach, G.G. 1983. An experimental test of the effects of predation risk on habitat use in fish. Ecology, 64(6): 1540-1548. doi:10.2307/1937508. 